\title{
JIGSAW PUZZLE IMPROVE FINE MOTOR ABILITIES OF UPPER EXTREMITIES IN POST-STROKE ISCHEMIC CLIENTS
}

\author{
Kusnanto, Eska Dwi Prajayanti, Harmayetty \\ Faculty of Nursing, Universitas Airlangga, Kampus C Mulyorejo Surabaya, 60115 \\ Email: eska_ners2012@yahoo.com
}

\begin{abstract}
Introduction: Ischemic stroke is a disease caused by focal cerebral ischemia, where is a decline in blood flow that needed for neuronal metabolism, leading to neurologic deficit include motor deficit such as fine motor skills impairment. Therapy of fine motor skills disorders is to improve motor function, prevent contractures and complications. These study aimed to identify the effect of playing Jigsaw Puzzle on muscle strength, extensive motion, and upper extremity fine motor skills in patients with ischemic stroke at Dr. Moewardi Hospital, Surakarta. Methods: Experimental Quasi pre-posttest one group control. The number of samples were 34 respondents selected using purposive sampling technique. The samples were divided into intervention and control groups. The intervention group was 17 respondents who were given standard treatment hospital and played Jigsaw Puzzle 2 times a day for six days. Control group is one respondent given by hospital standard therapy without given additional Jigsaw Puzzle game. Evaluation of these research is done on the first and seventh day for those groups Result: The results showed that muscle strength, the range of joint motion and fine motor skills of upper extremities increased $(p=$ 0.001) significantly after being given the Jigsaw Puzzle games. These means playing Jigsaw Puzzle increase muscle strength, the range of joint motion and upper extremity fine motor skill of ischemic stroke patients. Discuss and conclusion: Jigsaw puzzle game administration as additional rehabilitation therapy in upper extremity fine motor to minimize the occurrence of contractures and motor disorders in patients with ischemic stroke. Jigsaw puzzle game therapy capable of creating repetitive motion as a key of neurological rehabilitation in Ischemic Stroke. This study recommends using jigsaw puzzle game as one of intervention in the nursing care of Ischemic Stroke patients.
\end{abstract}

Keywords: Ischemic stroke, upper extremity fine motor, Jigsaw Puzzle

\section{INTRODUCTION}

Stroke is a disease that caused by the presence of ischemia (inadequate blood flow) or bleeding in the brain that leads to neurological changes, the death of brain cells, and function loss in movement, sensations, and emotions (Black and Hawks 2005; Lewis et al. 2007). Stroke is leading cause of disability in both developed and developing countries (American Hearth Association, 2010). A residual symptom of Ischemic Stroke is a blockage in the middle of cerebral artery lead to extremity weakness, especially fingers (Ringleb 2011; Kochanek et al. 2011). The long-term weakness of the fingers may result in muscle strength loss, decreased the range of motion and function loss of the movement, leading to interruption of fingers fine motor skills (American Stroke Association (ASA) 2013; Warlow, et al., 2007, Eng \& Harris, 2009). About $55 \%$ of Ischemic Stroke clients experienced residual symptoms such as hand weakness, especially fingers (Ward, et al. 2015; Kochanek et al. 2011). Treatment of disability in upper extremity is more difficult than lower extremity. Thus, seriously impact on rehabilitation progress in stroke. Then, proper treatment is needed to prevent permanent disability especially during the acute phase of stroke 48 hours post-stroke where the appropriate treatment can affect $33 \%$ of patients recovery within three months (Foley, et al., 2013; Ikawati 2010).

The decline in muscle cells function and impulse transmission impairment in motor neuron leads to inaccuracy and fingers coordination impairment in integrating the function of muscles, bones, and nerves. Disorders of the fingers coordination are called fine motor disorders (American Stroke Association, 2013). Appropriate stimulation was given by rehabilitation with repetitive motions therapy (Neistadt 1986). Repetitive exercises can be done using a jigsaw puzzle games. Jigsaw puzzle game is a puzzle game that consists of gripping, holding and manipulating objects using concentration and coordination between eyes and hands (Neistadt 1986; Foley DL, Morley KI, Madden PAF, et al. 2010).

Major Depression and the Metabolic Syndrome.Twin Research and Human Genetic; 13(4): 347-58. Howed that using the puzzle as treatment can stimulate the motor nerves in brain injury and giving rise the 
potential action as initial process of muscle contraction.

Preliminary studies conducted in January 2016 in Dr. Moewardi Hospital, Surakarta. The data showed that 5 of 6 clients suffered from fine motor skills impairment such as not being able to hold a cup, grasping the ball and adjusting buttons. The assessment using the Modified Motor Assessment Scale (MMAS). Measurements of fingers muscle strength using Hand Dynamometer on six clients of ischemic stroke who were treated for more than six days in Dr. Moewardi Hospital. The score obtained from 5 female clients were below 18.50 to 24.00 , while one female client has score below 18.00. The range of motion measurements of 6 clients is done using goniometer. The result showed that five clients suffered from finger extension where score obtained is below $30^{\circ}$. Physical rehabilitation is an exercise used Range of Motion (ROM) that focuses on muscle strength. Exercise to stimulate fingers strength have not done. Thus six clients suffered in fine motor impairment.

A fine motor impairment that often occurs in Ischemic Stroke needs proper nursing interventions to minimize the client's dependency in performing daily activities such as eating, drinking and dressing while undergoing treatment at the hospital. These study wants to prove the effect of jigsaw puzzles game to improve fine motor of upper extremity on post-ischemic stroke clients in Dr. Moewardi Hospital, Surakarta.

\section{METHODS}

The design of this research is quasiexperiment using the pre-post test in the control group. This design is used to compare the results of the intervention of two groups: intervention and comparison groups.

The population is all 58 clients ischemic stroke who were treated in Stroke Care Unit in Dr. Moewardi Hospital, Surakarta. The sample used is 17 of the treatment group and 17 of the control group. The research was conduct for a month. The independent variable is playing Jigsaw Puzzle. The dependent variable is muscle strength, extensive motion, upper extremity fine motor skills.

Research instruments are using Hand Grip Dynamometer to measure muscle strength, Goniometer for a range of joint motion and Modified Motor Assessment Scale
(MMAS) for measuring upper extremity fine motor.

\section{RESULT}

Table 1. Results of respondent equality analysis based on the frequency of attacks showed that between intervention and control groups had an equal frequency of attacks. Seen from the results of the statistical test with pvalue 0.366 (alpha $=0.05$ ) that there is no significant differences of group respondents (equivalent) based on the frequency of attacks .

Respondent equality analysis results based on age in Table 1 shows that between treatment and control group had an equal age. Seen from the results of the statistical test with p-value 0.155 (alpha $=0.05)$ that there is no significant differences (equivalent) in group respondents by age.

Respondent equality analysis results based on the affected extremity in Table 1 showed that between intervention and control groups had equal affected extremity. Seen from the results of the statistical test with $\mathrm{p}$ value 0.366 (alpha $=0.05)$ that there is no significant differences (equivalent) in group respondents based on the affected stroke extremity.

Table 2 showed that mean difference in fingers muscle strength after jigsaw puzzle games for six days in men of intervention group is 7.217 with standard deviation 1.790 , and mean difference of comparison group is 1,550 with standard deviation 1.693. Statistical test by using independent $\mathrm{t}$-test obtained $\mathrm{p}$ value 0.001 and alpha 0.05 , means that there is a significant effect of jigsaw puzzle games against the mean difference in fingers muscle strength of intervention and comparison groups in the male.

The mean difference in female fingers muscle strength after jigsaw puzzle game of intervention group 3.600 and standard deviation 0.761 while meaning the difference in comparison group 1,218 with standard deviation 0.560 . Statistical test by using independent $\mathrm{t}$-test obtained $\mathrm{p}$-value 0.001 with alpha 0.05 , means that there is a significant effect of jigsaw puzzle games against the mean difference in fingers muscle strength in intervention and comparison groups in the female. 
Jigsaw Puzzle Improve Fine Motor Abilites (Kusnanto et.al)

Table 1 Clients observation results based on age, gender, frequency of attacks, the affected extremity in Ischemic Stroke clients

\begin{tabular}{|c|c|c|c|c|c|c|c|}
\hline \multirow{2}{*}{ Client Characteristics } & \multirow{2}{*}{$\frac{\text { Intervention }}{\mathrm{f}(\mathrm{x})}$} & \multirow{2}{*}{$\frac{\text { Group }}{\%}$} & \multicolumn{2}{|c|}{ Comparison Group } & \multicolumn{2}{|c|}{ Total } & \multirow{2}{*}{$P$} \\
\hline & & & $f(x)$ & $\%$ & $\mathrm{~N}$ & $\%$ & \\
\hline \multicolumn{7}{|l|}{ Gender } & \multirow{4}{*}{0,640} \\
\hline Male & 6 & 35.3 & 6 & 35.3 & 12 & 35,3 & \\
\hline Female & 11 & 64.7 & 11 & 64.7 & 22 & 64,7 & \\
\hline Total & 17 & 100.0 & 17 & 100.0 & 34 & 100 & \\
\hline \multicolumn{7}{|l|}{ The frequency of attacks } & \multirow{4}{*}{0,366} \\
\hline The first attack & 10 & 58,8 & 8 & 47,1 & 18 & 52,9 & \\
\hline The second attack & 7 & 41,2 & 9 & 52,9 & 16 & 47,1 & \\
\hline Total & 17 & 100,0 & 17 & 100,0 & 34 & 100 & \\
\hline \multicolumn{7}{|l|}{ Age } & \multirow{5}{*}{0,155} \\
\hline $36-45$ & 0 & 0 & 6 & 35,3 & 6 & 17,6 & \\
\hline $46-55$ & 10 & 58,8 & 5 & 29,4 & 15 & 44,1 & \\
\hline $56-65$ & 7 & 41,2 & 6 & 35,3 & 13 & 38,3 & \\
\hline$\overline{\text { Total }}$ & 17 & 100,0 & 17 & 100,0 & 34 & 100,0 & \\
\hline \multicolumn{7}{|l|}{$\begin{array}{l}\text { The affected upper } \\
\text { extremities }\end{array}$} & \multirow{4}{*}{0,366} \\
\hline Right & 8 & 47,1 & 10 & 58,8 & 18 & 52,9 & \\
\hline Left & 9 & 52,9 & 7 & 41,2 & 16 & 47,1 & \\
\hline $\begin{array}{l}\text { Total } \\
\end{array}$ & 17 & 100,0 & 17 & 100,0 & 34 & 100,0 & \\
\hline
\end{tabular}

Table 2 Difference score of fingers muscle strength between intervention with comparison group after jigsaw puzzle intervention for six days

\begin{tabular}{cccccc}
\hline Variables & Group & $\mathrm{n}$ & $\begin{array}{c}\text { Mean } \\
\text { Difference } \pm\end{array}$ & $\begin{array}{c}\text { Standard } \\
\text { deviation }\end{array}$ & $p$ \\
& Male & & & & \\
\cline { 2 - 6 } $\begin{array}{c}\text { Muscle } \\
\text { strength }\end{array}$ & Intervention & 6 & 7,217 & 1,790 & 0,001 \\
\cline { 2 - 6 } & Comparison & 6 & 1,550 & 1,693 & \\
\cline { 2 - 6 } & Female & & & & 0,001 \\
\cline { 2 - 6 } & Intervention & 11 & 3,600 & 0,761 & \\
\cline { 2 - 6 } & Comparison & 11 & 1,218 & 0,560 & \\
\hline
\end{tabular}

Table 3 showed that mean difference in the range of motion of the fingers after jigsaw puzzle game for six days in intervention group 6.65 with standard deviation 2.029 , while the comparison group 2.82 with standard deviation 2.942. Statistical test using independent $t$-test obtained p-value 0.001 with alpha 0.05 , means that there is a significant effect of jigsaw puzzle games against the mean difference in the range of motion of the fingers between intervention and comparison groups.
Table 4 showed that mean difference of upper extremity fine motor after jigsaw puzzle game for six days in intervention group 3.29 with standard deviation 0.588 , while the comparison group 0.94 with standard deviation 0.772. Statistical test using independent t-test obtained p-value 0.001 with alpha 0.05 , means that there is a significant effect of jigsaw puzzle games against mean difference upper extremity fine motor between intervention and comparison groups. 
Table 3 Results of the mean difference in range of motion of the fingers in intervention and comparison group after jigsaw puzzles intervention for six days

\begin{tabular}{cccccc}
\hline \multicolumn{1}{c}{ Variables } & Group & $\mathrm{N}$ & Mean \pm & $\begin{array}{c}\text { Standard } \\
\text { deviation }\end{array}$ & $p$-value \\
\hline $\begin{array}{l}\text { Range of motion } \\
\text { of the fingers }\end{array}$ & Intervention & 17 & 6,65 & 2,029 & \multirow{2}{*}{0,001} \\
\cline { 2 - 5 } & Comparison & 17 & 2,82 & 2,942 & \\
\hline
\end{tabular}

Table 4 Results of the mean difference of upper extremity fine motor between intervention and comparison group after jigsaw puzzle intervention for six days

\begin{tabular}{cccccc}
\hline Variables & Group & $\mathbf{N}$ & Mean \pm & $\begin{array}{c}\text { Standard } \\
\text { deviation }\end{array}$ & $\boldsymbol{p}$-value \\
\hline $\begin{array}{c}\text { Upper extremity } \\
\text { fine motor }\end{array}$ & Intervention & 17 & 3,29 & 0,588 & 0,001 \\
\cline { 2 - 5 } & Comparison & 17 & 0,94 & 0,772 & 0,001 \\
\hline
\end{tabular}

\section{DISCUSSION}

Based on the results of the study before jigsaw puzzle games intervention indicated that the score of muscle strength between male and female had a different range of score. At 11 females clients in intervention group had score of muscle strength below 18.00 which means that all females in these study experienced a decrease in muscle strength and less category, means that there is a lack of muscle movement or weak areas in accordance with the dictates like the palm face down, or straight twisted but if detained a bit was not able to move. At six males clients in the intervention group had a score of muscle strength below 27.00 means in less category.

The same condition is also seen in comparison group before intervention by hospital standard. A score of muscle strength of the fingers on the 11 females and six males also included in less category.

The decreasing of muscle strength of the fingers is caused by the failure of sensory nerves to deliver impulses to motor nerves lead to the failure of potential action in the muscle. Decreased muscle strength in Ischemic stroke occurs largely due to component central nervous system failure in impulse conduction mechanism resulting mild to severe weakness effect on the contralateral side and caused limitations in movement (LeMone \& Burke 2004). Research conducted by Misbach \& Soertidewi (2011) said that from data survey of 28 hospitals in Indonesia about 95\% clients of after ischemic stroke decreased in muscle strength.

Muscle strength is muscle ability to withstand the load both external and internal. The muscle strength of the fingers is associated with neuromuscular system relates to how large the ability of the nervous system to activate the muscles to perform contractions. The fewer muscle fibers are activated, produced smaller muscle strength (Irfan, 2010).

One key success of physical therapy in ischemic stroke with decreased muscle strength is a repetitive movement that will result in more activated muscle fibers. Repetitive movements will be able to activate the motor unit, thus causing repetitive muscle contractions (Neistadt 1986). Repetitive movements that specific to the hand movement is effective as the initial response to muscles and brain activity (Neistadt 1986). Proper selection of media that contains coordination between the nervous system, musculoskeletal system, motor and sensory systems are capable of accelerating the development of fine motor skills. Puzzle is one of the media used to rehabilitation nursing interventions in Ischemic stroke

A jigsaw puzzle is a game that requires coordination of the fingers and eyes to compose divided picture into an integral part (Alajlan 2009) At 17 client of interventions group play jigsaw puzzle game two times a day for six days showed the increasing of muscle strength score. At 11 female clients, muscle strength scores increased above of 18.00. After jigsaw puzzle game 11 clients demonstrated fair category of muscle strength, means that muscles able to contract but can not move the body against gravity, but when gravity is removed by changing the body position, muscles can move the full body.

Increased muscle strength also occurred in the male intervention group. After six clients play jigsaw puzzle games showed an increase in muscle strength score above of 27.00. After jigsaw puzzles intervention 5 respondents were in fair category, means that the muscles able to 
contract but can not move the body against gravity, but when gravity is removed by changes in body position, muscles can move the full body, and 1 client in fair category means that the muscles of the fingers able to contract and move the full body against gravity.

Effect of jigsaw puzzle games on muscle strength of the fingers is evidenced by statistical test using paired T-test, showed that female intervention group $\mathrm{p}$-value $\leq 0,05=0.001$, means that there is the effect of jigsaw puzzle game on the muscle strength of the fingers in a female with ischemic stroke who experience decreased muscle strength. An intervention group of male $p$-value $\leq 0.05=0.001$, means that there is the effect of jigsaw puzzle games on muscle strength of the fingers in Ischemic Stroke who experience decreased muscle strength.

Different conditions showed in the comparison group. About 3 of 11 females clients had scored above 18.00 or in fair category after standardized hospital intervention. About 3 of 6 males client remains in the poor category. This condition occurs because the hospital standard therapy given to a range of motion therapy of the fingers conducted once a day without any additional therapy.

Effect of hospital standard therapy to the muscle strength of the fingers is evidenced by statistical test using paired T-test, showed that female intervention group $\mathrm{p}$-value $\leq 0,05=$ 0.001 , means that there is the effect of standardized hospital therapy on the muscle strength of the fingers in women with Ischemic Stroke who experienced decreased muscle strength. In male intervention group p-value $\geq$ $0.05=0.075$, means that there is no effect of standardized hospital therapy on muscle strength of the fingers in men with Ischemic Stroke who experienced muscle strength decreased.

The muscle strength of the fingers in the intervention group of jigsaw puzzles game show greater improvement than hospital standardized therapy. These happened because jigsaw puzzle games stimulated muscles contraction causing $\mathrm{Ca}^{2+}$ lines open in sarcoplasmic reticulum then stimulate potential actions ( Shen Li, 2014). Potential actions that continuously occur may activate many motor units in muscle fibers. Those will continue to contract muscles and then muscle strength increases.
Repetitive active movements in jigsaw puzzle game are expected to increase muscle strength. The more active movements when the rehabilitation, the results obtained will be more optimal. Supported research conducted by (Prok 2016) said that there is significant correlation between fingers active movement exercises effect to increase the muscle strength of the fingers on Stroke client. The same results conducted by Fatkhurrohman (2011) also pointed out that upper extremities exercise on hemiparesis by moving fingers three times a day for seven days would increase the muscle strength of the fingers. Those were proved by statistical test results $\mathrm{p}=0.001$.

Differences in muscle strength values in intervention and comparison groups can be seen from the difference value of muscle strength that had been increased in each client. From the statistical test by independent T-Test showed that female group p-value $\leq 0.05=0.001$, means that jigsaw puzzle games had more effect on muscle strength increase than standardized hospital therapy. The same thing is also shown in the male group $\mathrm{p}$-value $\leq 0.05=$ 0.001 .

On recurrent attacks client will face longer rehabilitation process. This rehabilitation process is due to sudden occlusion of blood vessels that previously normal in the first attack allegedly as a result of the progression of stenosis/occlusion of blood vessels that increase the risk of vascular disruption event (Shin et al. 2017). It means that more attacks frequency on Ischemic Stroke leading to longer rehabilitation process than the first attack. (Wirawan 2009) said that long rehabilitation process is influenced by the severity and extent of the lesion of the brain affected by stroke attack.

Based on the results of the study before jigsaw puzzle games intervention indicated that 11 female clients in the intervention group had a range of motion value measured at the metacarpalphalange (MCP). At the time of the finger extension under $10^{\circ}$ were included in a poor category means that the joint can move, but there were obstacles. At six male clients comprehensive MCP joint motion value is under $10^{0}$ were included in a poor category means that the joint can move, but there were obstacles. The same condition is also seen in the comparison group before hospital standard intervention. The range of joint motion $\mathrm{MCP}$ value of finger extension on 11 female clients and six male clients were also included in the 
poor category, means that the joint can move, but there were obstacles such as pain in the finger joints when performed extension. This barrier occurs due to joints had not being moved in a long time.

The range of joint motion is the maximum capacity that can be achieved by the joint (Yuliastati. 2011). Decreased muscle strength also contributed to the decline of the joint range of motion. This happened because the bones and joints of the motor system coordinate with each other to produce movement. The force produced by the muscle strength produce synovial fluid to lubricate the joints and formed a layer between the surfacerelated films that separates the cartilage to not rub against each other, so the range of motion will increase (Kushartanti, 2007).

Jigsaw puzzle game is improving the muscle strength of the fingers, also increased the range of motion. Improvement in range of joint motion occurred on eight clients those in fair category, means that joints capable of full moving and against gravity without resistance. The range of joint motion is one of the fine motor component other than muscle power. Effect of jigsaw puzzle games against the range of joint motion of the fingers is evidenced by the statistical test using Wilcoxon Signed Rank Test which showed that female intervention group p-value $\leq 0,05=0.001$, means that there is effect of jigsaw puzzle game on range of joint motion of the fingers in women with Ischemic Stroke who experienced decreased muscle strength. In the male intervention group $\mathrm{p}$-value $\leq 0.05=0.001$, means that there is the effect of jigsaw puzzle games on a range of joint motion of the fingers in men with Ischemic Stroke who experienced decreased muscle strength.

In contrast to the comparison group was given hospital standard intervention. The effect of hospitals standardized therapy to range of joint motion of the fingers is evidenced by statistical test using Wilcoxon Signed Rank Test, showed that female intervention group $\mathrm{p}$ value $\leq 0,05=0.001$, means that there is effect of standardized hospital therapy to range of joint motion of the fingers in women with Ischemic Stroke clients that experience decreased range of joint motion. In male intervention group $\mathrm{p}$-value $\geq 0.05=0.075$, means that there is no effect of the hospital standardized therapy to a range of joint motion of the fingers in a male client with Ischemic Stroke that decreased the range of joint motion.
MCP Range of joint motion differences between intervention and comparison groups can be seen from the difference in value between each client. Statistical test using MannWhitney test showed that $\mathrm{p}$-value $\leq 0,05=$ 0.001 , means that jigsaw puzzle games more influential on the increase of MCP range of joint motion when extention than hospital standardized therapy.

The repetitive motion produced by jigsaw puzzle games able to increase the range of motion of the fingers then increase the MCP joint motion. Repetitive motions of MCP joint will cause the cartilage surface between two bones friction against each other. Emphasis on cartilage due to the movement will push the water out of the matrix of cartilage into the synovial fluid, the activity at the joints will maintain synovial fluid which is a joint lubricant so that the joint can move to the maximum (Winters 2004). Supported research conducted by Victoria et.al (2014) revealed that active exercise on the fingers could increase the range of joint motion of the fingers, by activating more muscle fibers on the fingers.

Based on the research revealed that the intervention group of 11 female clients upper extremity fine motor's score is below of 2 . In the intervention group of 6 male clients also demonstrated value of upper extremity fine motor skills below of 2 , means that the average client conditions have not been able to open the top of the pen and put it again (client took the top of the pen is placed far edge of the table and brought closer back near the body). These study showed that the weaker muscle strength and the smaller range of joint motion would result in decreased fine motor skills of the upper extremities.

Yudanto (2012) said that the development of fine motor skills parallel with the development of the nervous system and muscles, so fine motor skills is determined by the maturity in integral function of body systems, especially the nervous system and body movement (bones, muscles, and joints). Decreased muscle strength and range of joint motion that occurs continuously also cause fine motor skills disturbances (Eng \& Harris, 2009). This is because fine motor skills are organizing between muscles and joints with the nervous system (Yudanto, 2012). So, if there is no movement or stimulation that stimulates muscle contraction will cause fine motor skills disturbances. Therefore, to increase the fine 
motor skills is necessary to provide stimulation which includes nerve coordination, muscle movement, and joint movement. So, that will provide balance in the development of fine motor coordination. One of the motion stimulation which includes three aspects is through Jigsaw Puzzle Game.

Jigsaw puzzle game is a puzzle game that requires precise coordination of sensory and motor systems to install parts of a puzzle as expected picture. Neistadt (1986) stated that the puzzle game performed on the client with a head injury could improve fine motor skills of the fingers so that the client can perform daily activities.

Puzzle exercises used to develop eye contact, attention and concentration as well as the eye coordination, hand, and train concepts. Giving jigsaw puzzle two times a day for six days led to an increase in upper extremity fine motor skills. Of the 17 clients, both men and women had fine motor value above of 2 , means the client can draw horizontal and vertical lines are alternately 10 times within 20 seconds (at least five lines must be touched and stopped in a vertical line. The line is made should be about $10 \mathrm{~cm})$.

Mean difference between fine motor skills value in intervention group before and after the jigsaw puzzle game is evidenced by the statistical test using Wilcoxon signed rank test showed $\mathrm{p} \leq 0,05=0.001$, means the provision of additional therapy such as jigsaw puzzle effect on the improvement of fine motor skills of the upper extremity.

Jigsaw puzzle game is a game that requires fingers and eye coordination to develop an image that split into several parts. Jigsaw means eliminating a pattern in the image sequence so that game would be repeated to find that section. Thus the players being motivated and encouraged to continue to arrange and find the missing pattern repeatedly. This repetition is expected to train the client fine motor skills (Alajlan, 2009).

Research conducted by Maureen (2004) argued that the game using the puzzle as the media for six days were carried out at 45 clients can stimulate motor nerves with a head injury and risen the potential action as initial process of muscle contraction. In these studies indicated $\mathrm{p}$-value $=0.01(\alpha=0.05)$, means that there is a significant effect on using puzzle media to improve fine motor skills in upper extremity in head injury clients.
Jigsaw puzzle games could motivate clients to discipline in the exercise. Images are presented in this game attract clients to play arranging piece into a series of corresponding images continuously. Wirawan (2009) revealed that client self-motivation is one factor that influences the outcome of the rehabilitation process. This statement is supported by research conducted by Ariyadi (2010) said that high motivation of client in Ischemic Stroke rehabilitation process would produce good and fast outcome, interesting media used to increase client self-motivation (Hariandja, 2013)

A similar study conducted by Smith (2000) of 44 pre-school children using Puzzle and $81 \%$ pre-school children increased fine motor skills. Wijanarko (2008) said that by giving a puzzle game for children aged 4-5 years can improve fine motor skills.

In contrast to the comparison group given hospital standardized intervention showed that before the intervention, upper extremity fine motor value is below 2 in both male and female clients. After standardized hospital therapy, the value increasing of fine motor skills occurred in 15 clients, both male, and female, while two clients were not increased fine motor skills. After standardized hospital therapy, only four clients that had fine motor skills value above 2 .

Differences in fine motor skills value in comparison group before and after hospital standardized therapy evidenced by statistical test using Wilcoxon signed rank test showed $\mathrm{p}$ $\leq 0,05=0.01$, means that the provision of standardized hospital therapy affects the increasing of upper extremity fine motor skills.

Differences value between the increasing of fine motor skills of upper extremity also can be seen between intervention and comparison groups. Value difference of fine motor upper extremity in intervention group reaches 23.29 higher than comparison group increased only by 0.94 . This difference proved that jigsaw puzzle games could improve upper extremity fine motor skills in intervention group larger than the comparison group.

Difference score in upper extremity motor between given and not given in additional jigsaw puzzle therapy was because of difference in duration and intensity of therapy. Lack of motivation during exercise also contribute to the success of therapy (Wirawan 2009). Hariandja (2013) said that the key success of neurological rehabilitation is duration and intensity of exercise. 
A jigsaw puzzle is a game that requires coordination of fingers and eyes to develop an image that split into several parts. Jigsaw means eliminating a pattern in image sequence that game would be repeated to find that image section. Thus the players being motivated and encouraged to continue arranging and finding the missing pattern repeatedly. The repetition is expected to train the client fine motor skills (Alajlan 2009). Active movements that repeatedly occur in this game is expected to increase muscle strength. As a more active movement that occurs during rehabilitation exercises, the results obtained will be more optimal.

If cell membrane produced by the cell membrane is strong enough, the potential action will flow rapidly into all cell membranes. Muscles as locomotor active have irritability indicated by responding process to stimuli (recognize and respond to stimuli/stimulus) the muscles directly without relying on usual neural tissue that activates muscles. Therefore, if skeletal muscle cells or muscle fibers are given a stimulus above or normal threshold, then the muscle cell will fully contract. Otherwise, if the stimulus of the muscle is under threshold/ subminimal, the muscle cells will not contract at all. Subminimal threshold stimulus may cause contraction response with the condition given in fast and several times (Feriyawati 2005).

Jigsaw puzzle games using interesting images, inexpensive and safe, so clients are interested and eager to perform the therapy. An interesting and inexpensive therapy used to improve motivation during the acute phase of post-stroke rehabilitation is needed for disciplined in client therapeutic process.

Supporting research conducted by Prok (2016) said that there is a significant correlation between active motion exercises effect on hand grasping the ball toward increasing muscle strength of the fingers on Stroke client. In intervention group given grasping the ball three times a day for seven days. The comparison group gave according to hospital standard therapy one times a day. Both groups showed an increase in muscle strength of the fingers but with grasping the ball as additional therapy, the difference in muscle strength seen more significant with $\mathrm{p}$-value 0.001 .

Other supporting studies is research conducted by Maureen (2004), suggested that puzzles therapy more effective than using conventional therapies. There are significant differences in fine motor skills and muscle strength in clients who were treated using puzzle and conventional. In these study, explained that clients more interested using puzzle for therapy even though the duration is longer. Clients feel challenged to finish the puzzles.

\section{CONCLUSIONS}

Intervention using Jigsaw Puzzle Games can improve upper extremity fine motor skills on the client after Ischemic Stroke. The increase in fine motor skills of upper extremities followed by increasing of muscle strength of the fingers and increase the range of motion in metacarpalphalange (MCP).

Continuing Jigsaw Puzzle game as one independent action for medical-surgical nurses especially neurology nurse so that clients can minimize muscle stiffness after Ischemic Stroke. Further research conducted by group clients based on gender. Can be used as one of the additional hospital therapy in the rehabilitation process after Ischemic Stroke with low cost, materials that are safe for the client and easily obtained. Giving a strong motivation and family support is an important factor in patients rehabilitation process after ischemic stroke with upper extremity fine motor impairment.

\section{REFERENCES}

Alajlan, N., 2009. Solving Square Jigsaw Puzzles Using Dynamic Programming and the Hungarian Procedure Naif Alajlan Advanced Lab for Intelligent Systems Research, Department of Computer Engineering,. , 6(11), pp.1941-1947.

Black,J.M., dan Hawks,J.H.2005. Medical Surgical Nursing. New York. Elsevier

Fatkhurrohman M. 2011. Teknologi Stimulasi Elektrik (Elektrical Stimulation) Bagi Pasien Yang Mengalami Kelemahan Otot Dan Nyeri. Keperawatan Medikal Bedah FIK-UI

Feriyawati, L., 2005. Anatomi Sistem Saraf Dan Perannya Dalam Regulasi Kontraksi Otot Rangka.

Foley DL, Morley KI, Madden PAF, et al. 2013. Major Depression and the 
Metabolic Syndrome.Twin Research and Human Genetic; 13(4): 347-58.

Hariandja, 2013 Identifikasi Kebutuhan Akan Sistem Rehabilitasi Berbasis Teknologi Terjangkau Untuk Penderita Stroke di Indonesia, Lembaga Penelitian dan Pengabdian kepada Masyarakat Universitas Katolik Parahyangan.

Haris J E, Eng J J., 2009. Paretic UpperLimb Strength Best Explains Arm Activity In People With Stroke http://ptjournal.apta.org/content/87/1/8 8.full.pdf + html. Diakses pada tanggal 16 April 2016.

Irfan, Muhammad. 2010. Fisioterapi bagi insan stroke. Yogyakarta : Graha ilmu

Ikawati, Z., 2010. Farmakologi Molekuler, Yogyakarta: UGM Press.

Kochanek, K.D. et al., 2011. National Vital Statistics Reports Deaths : Final Data for 2009. , 60(3).

Kushartanti (2007) Pengaruh Latihan Range Of Motion (ROM) Terhadap Fleksibilitas Sendi Lutut Pada Lansia Di Panti Wreda Wening Wardoyo Ungaran, Nurse Media Journal of Nursing Vol 1, No.2.

Li, Shen et al. "Infarction of the Corpus Callosum: A Retrospective Clinical Investigation." Ed. Jeroen Hendrikse. PLoS ONE 10.3 (2015): e0120409. PMC. Web. 2 June 2017.

LeMone, P.T. \& Burke, K.M., 2004. Medical-Surgical Nursing: Critical Thinking in Client Care, Pearson Prentice Hall: New Jersey.

Lewis, S.L. et al., 2007. Assessment and Management of Clinical Problems Volume 2., Pennsylvania: W.B Saunders.

Neistadt, M.E., 1986. The Effects of Different Functional Fine Motor With Brain Injury.

Prok, W., 2016. Pengaruh latihan gerak aktif menggenggam bola pada pasien stroke diukur dengan handgrip dynamometer. , 4(April).

Ringleb, S. I., Dhakal, A., Anderson, C. D., Bawab, S. and Paranjape, R. (2011),
Effects of lateral ligament sectioning on the stability of the ankle and subtalar joint. J. Orthop. Res., 29: 1459-1464. doi:10.1002/jor.21407

Smith- Jane Case.2000. Effects of Occupational Therapy Services on Fine Motor And Functional Performance in Preschool Children. American Journal of Occupational Therapy. Vol 54, 372-380

Shin, D.H., Lee, P.H. \& Bang, O.Y., 2017. Mechanisms of Recurrence in Subtypes of Ischemic Stroke. , 62.

Warlow, C.P., Dennis, M.S., Gijn, V.J., Hankey, G J., Sandercock, P.A., Bamford, J.M., 2007. Stroke, In : a Practical Guide to Management. 1st ed. London: Blackwell Science

Wijanarko, H., 2008. Efektifitas Alat Permainan Edukatif Puzzle Terhadap Perkembangan Motorik Halus Anak Usia 4-5 Tahun Berdasarkan DDST, Semarang: Thesis. Universitas Diponegoro.

Winters, M., 2004. Passive versus active stretching of hip flexor muscles in subjects with limited hip extension: a randomized clinical trial.

Wirawan, R.P., 2009. Rehabilitasi Stroke pada Pelayanan Kesehatan Primer, Jakarta: SMF Rehabilitasi Medis RS Fatmawati.

Victoria, Arlies Z, et al. 2014. Pengaruh Latihan Lateral Prehension Grip Terhadap Peningkatan Luas Gerak Sendi (LGS) Jari Tangan Pada Pasien Stroke di Rsud Dr. H Soewondo Kendal. Stikes Telogorejo Semarang

Yudanto (2010). Stimulasi Gerak Dasar Siswa Sekolah Dasar Kelas Bawah. Jurnal Pendidikan Jasmani Indonesia, Volume 4, Nomor 2, Nopember 2007. FIK UNY

Yuliastati., 2011. Pengaruh Latihan Rentang Gerak Sendi Terhadap Kekuatan Otot dan Luas Gerak Sendi Anak Dengan Tuna Grahita Sedang di Sekolah Luar Biasa Kota Bogo, Thesis. Universitas Indonesia. Jakarta. 